\title{
Sharing ethnographic love
}

\author{
Entretien avec Catherine Besteman ${ }^{1}$
}

\author{
Par Isabelle Jabiot, Maïté Maskens \\ et Carine Plancke
}

\section{Love and research history}

We had the opportunity to have a look at your paper "On Ethnographic Love", published in the book "Mutuality" (Sanjek 2014). Until then, you had been working on several topics such as violence, racism, activism, humanitarian action, etc. How did you come to work on love? How would you describe the way love appeared on your academic path and became part of your research?

For the previous decade, I had been thinking a lot about the things that distinguish anthropology from journalism, activism, and literary non-fiction. It seemed to me that anthropology's signature feature, in addition to its ethical code (that ethnography should not be harmful to research subjects), is the methodological practice of close, intimate, interpersonal relationships based on mutual trust, respect, and reciprocity. Because of ethnography's temporal stretch and the anthropologist's engagement in conversations and relationships that grow and deepen over time, ethnography pulls the ethnographer into long-term personal relationships that become emotionally meaningful. Whether we admit it or not, caring about these relationships shapes and influences how we narrate stories. These thoughts were very much present when I was writing Transforming Cape Town, which includes the most personal reflections about fieldwork and critical theory of all my publications, partly in response the insistence of some of my interlocutors that I must attend to the emotional life of ethnography in order to honestly address the trenchant topic of race in postapartheid South Africa.

While my work in Cape Town provoked me to consider the affective and emotional dimensions of ethnography, Roger Sanjek's invitation to reflect in a book chapter on how mutuality defines anthropology offered an opportunity to name the sentiments I was feeling and exploring. By identifying the emotional landscape of the ethnographic encounter as a form of love, I obligated myself to explore the idea of ethnographic love both in my own work and in the publications of fellow scholars.

1 Professeure d'Anthropologie, Colby College. 


\section{Love and research conditions}

Do you think that the conditions and the environment for doing research in the human and social sciences have inhibited talk about love? Does the topic lack a certain legitimacy? If so, do you have some anecdote that could illustrate this?

Yes, I would agree that there is a reluctance to discuss how the emotion of love enters, animates, infuses, and complicates our work. It is impossible to measure or accurately assess the significance of love on narration and analysis, and naming love as a reason or justification for ethnographic work is still met with accusations of impartiality, even in the current post-objective anthropology. When I wrote in a scholarly article for a peer reviewed journal that love can be a powerful motivation for ethnographic work, one reviewer wrote that this concept was "just too yucky" to mention. Seriously? Love is too yucky?

Do you think that love, just like everything else that deals with the emotional and intersubjective field, is considered to be subjective, irrational, feminine, etc. and that this makes talking about love a taboo or a sensitive issue?

I suspect that a discomfort with the squishiness of love and its association with irrational affect and the suspension of objective judgment (think of the phrase "Love is blind") makes scholars squeamish about acknowledging that they might love their research interlocutors. Admitting that one loves one's research subjects - even now, when ethnographers are expected to critically and reflexively examine their positionality in relation to their research subjects across the domains of gender, race, sexual orientation, class, and citizenship - is still taboo. Perhaps this sensitivity reflects the internal patriarchy that continues to influence ethnography despite our efforts to kill the masculinist colonial image of the anthropologist as the lone objective, unbiased, scholarly hero-adventurer.

How was your publication received? Did you receive very positive reactions or arguments of refutation?

I have heard from several colleagues that they felt relief to read a call for a more emotionally nuanced acknowledgement of our research relationships, and that the idea of ethnographic love captures an important component of their ethnographic experience. But I have also received critiques. Some have suggested that love is an inappropriate emotion to claim in ethnographic work because love is always political, oppressive, and controlling. Another suggested that the concept of ethnographic love can offer a blind that obfuscates the hierarchies inherent to ethnographic work.

\section{The impact of love on anthropology}


Does a consideration of love in anthropology allow to do anthropology in a different way? You say that it is because you had an experience of ethnographic mutuality that it was possible for you to write on apartheid. What extra does love bring? How does love allow to write and to think in an anthropological way? On the other hand, do you think that without this feeling it is not possible or difficult/delicate to talk about certain topics?

I'm advocating for an honest acknowledgement of the existence of love, when such sentiment exists, in our ethnographic relationships, but I'm not suggesting that all ethnographers feel love for their research subjects, or that all ethnographic relationships include loving care and mutuality. I found that when I acknowledged the importance to my personal life of the emotionally meaningful relationships I developed through ethnographic research I was able to write more honestly, powerfully, and confidently about challenging topics like racism, hatred, resentment, inequality, poverty, and so forth. Acknowledging the personal and emotional stake I had in the lives of my interlocutors, and that they had in mine, helped me better to articulate my unfolding understanding of racial and class dynamics in Cape Town. The extra that love brings is that personal stake, empathy, and a passion for understanding. But of course it is quite possible to do excellent ethnographic work in the absence of ethnographic love, and in contexts of acute ethnographic discomfort and moral turbulence (such as when one is writing about communities who engage in practices or hold values antithetical to those of the ethnographer, such as a dedicated anti-racist studying neoNazi groups, or an avowed secularist studying fundamentalists, and so forth. But even in these contexts ethnographic love may still be possible).

You also emphasize that the experience of ethnographic mutuality has led you to a different writing style. In particular, you suggest that it has been possible for you to describe associated qualities such as confidence and reciprocity. Do you think love allows to say things that, else, would remain unsaid?

I would not argue that the acknowledgment of ethnographic love allows the ethnographer to say things that otherwise would be impossible or unthinkable. Rather, I'm arguing that the acknowledgement of ethnographic love enables a certain perspective, confidence in writing, passion for the subject, invested care in the possible impact of representation, and possibly a greater commitment to collaborative research, writing, and publicizing methodologies than what otherwise might be the case.

You claim that photography has been a tool to account for your ethnographic love and to show Somalian people in a different way. Do you think that the intimate experience of the field, the people and the discipline of anthropology, or shortly ethnographic love, can be a source for developing new modes of writing and for using new media?

Yes, absolutely. Acknowledging ethnographic love can be liberating within the scholarly paradigm because the reciprocity and mutuality that characterizes love can ena- 
ble alternative forms of engagement, conversation, imaginings, and collaborations to emerge from the ethnographic encounter. This is certainly possible in the absence of ethnographic love, of course, but the playful, trusting, intimate, and nurturing dimensions of love can spark creative expression. Ethnographic love might inspire the ethnographer to seriously pursue alternative forms of artistic production and community engagement far beyond the scholarly expectation or imperative, prioritizing the desires and goals of the research interlocutors rather than the professional career.

\section{From love to the vocation of anthropology}

In your text, you recall the argument of V. Dominguey (2000) according to which love in itself is a scientific argument. Could you develop this proposition as you see it? Should this consideration not be extended, beyond anthropology, to all human and social sciences and to science in general? Is love as a driving force for doing research typical for anthropology? Do you think that there are other domains where love acts as a motivation in a similar way? Other disciplines, for instance? Or other domains such as art, literature, photography, etc?

Dominguez argued that an acknowledgment of the impact of love on our research could make ethnographic writing more rather than less powerful; that writing through the lens of love and the sorts of commitments that love carries offers ethnographic work greater gravitas and meaning. I do not think this argument is limited to ethnography. Love is undoubtedly a sentiment animating the work of a range of people, from those who work with forests, wildlife, rivers and rocks to those who work in labs and those who produce art.

Your defence of ethnographic love and your need for expressing it seem profoundly linked to your willingness to "humanize". We especially think here of what you say about the role of photography and the ambition you had in organising a photo exposition on Somalians. Do you think that anthropology and the human and social sciences in general suffer from a lack of humanity? According to you, is this lack linked to a "scientist" view or to the primacy given to objectivity and to the continuous search for legitimacy? How would you explain that anthropology and ethnographers can lack humanity when they work with and on human beings?

Years ago, in a AAA presentation, Carolyn Nordstrom asked for anthropological theory that lives and breathes. She was arguing for theory that accounts for and carries sentiment, affect, and empathy, reminding her audience that anthropological theory must be able to carry and illuminate emotion as well as structure and meaning. I think anthropologists are attentive to the power of our perspective to teach and provoke empathy and to the understanding that theory is not only useful but essential to this project. But the focus in the question on 'humanity' is intriguing here, especially 
in relation to anthropological interest in the post-human, for example. I no longer think that ethnographic love is necessarily tied to the concept of 'humanity.

You consider that anthropology has an important place in our global world. In this respect, the critical insight anthropology gives should be referred to in contemporary social debates. You are engaged, by the way, in ethic anthropology (NCA - Network of Concerned Anthropologists, for instance). Moreover, the topic of love is intrinsically linked to your activist view of anthropology (citizen activism and contemporary humanist considerations), hence to an explicit desire to change society through anthropology. Has ethnographic love caused this engagement or is it rather a co-construction? How would you describe your personal and your research trajectory where in the end these two dimensions meet?

This is a very large question and difficult to answer briefly. In my own professional biography, an awareness of ethnographic love and a desire to use anthropology for social change have grown together. I'm not sure how it would be possible not to feel personally and professionally invested in the lives of those with whom one has formed long-term ethnographic relationships in a way that motivates one to positive collaborative action.

You state, quite rightly, that anthropology is defined above all by its willingness and desire to understand how and what others think with the aim to grasp how the world is like for our interlocutors. Do you think that this endeavour sufficiently transcends the field and the moment of doing ethnography? Do anthropologists sufficiently use their altruist capacity beyond the field, in their academic relations and in their own life? Would there not be a kind of "schizophrenia" in the anthropologist who is capable to use this capacity in a different way according to the contexts and the prevailing interests and according to the capacity of self-transcendence? To what degree are altruism and love linked?

Altruism is a tricky concept, because it implies that beneficiaries can be disentangled. I don't think this is the case. What is beneficial to my research interlocutors, or my students, or my neighbors, or my children's friends will likely benefit me too, although perhaps not always in ways I might most desire or prioritize. The idea of the common good - of prioritizing the things that benefit most people - is a critically important one, and one that anthropologists are well positioned to accentuate. Love clearly is in play here.

Would it not be exactly this that anthropology has to offer to the world: a certain way of looking at and respecting alterity (in your terms)? Beyond the idea that anthropology can contribute to the development of social justice and the realization of a good society, you evoke "a contamination of realms". Would it not be this way of looking at the Other that one should defend at home or, in every case, in the West, within and outside of the domain of research and of the scientific world? 
Yes. Again, this question brings us back to the concept of the common good.

Besides the fact that ethnographic love urges for citizen engagement and for a defence of certain values, does it also nourish in you a kind of intellectual love or a love for the discipline, for anthropology or for science in general?

Absolutely. Anthropology enables and values personal investment in one's research. Our fieldwork methodology practically demands it: it's an all-in undertaking. That is tremendously exciting, challenging, rewarding, and stimulating.

\section{The effects of love on love}

You explain in your text your idea of ethnographic love as it arises from experiences of mutuality and love in the human encounter. Meanwhile, you do not give direct examples coming from your field. Could you share with us some events or stories of encounters or relations that illustrated your feeling, how it emerged, how it was consolidated, etc.

Love emerges within and becomes apparent within networks of care, as an example: caring for each others' children, sharing concerns about aging parents, feeling invested in each other's hopes and dreams, revealing secrets, growing trust; all the same experiences and expressions of love that characterize other loving relationships can come to characterize ethnographic love. The primary differences are: ethnographic love emerges from the ethnographic encounter and is initially based on that encounter and the expectations, responsibilities, and obligations attendant to ethnography; ethnographic love is the basis for professional and scholarly production and thus demands a particular ethical accounting of benefits.

Has your love relationship to ethnography led you to take love as a research subject? Did you study love in the societies where you have worked? Do you think there is something universal in the feeling of love?

I have not directed scholarly attention to love as a research subject, nor do I want to. I'm not sure why. I suspect it has something to do with a desire to allow love to remain a bit inchoate, murky, and indescribable as a subject.

You associate love with mutuality, respect and confidence. However, you do not directly touch upon the question of generosity and sharing. Would you associate them with love? How? Are other values intrinsically linked to love?

Oh yes. Generosity and sharing are, for me, part of mutuality and ethnographic love. Mutuality is not just about mutual recognition and respect; it is also about generosity and sharing, as well as sincerity and trust. Again, generosity and sharing, as well as 
sincerity and trust, make ethical demands on the ethnographic encounter and on expectations and responsibilities surrounding scholarly ethnographic production.

Your view on ethnographic love and your anthropological engagement are also intrinsically linked to issues of morality and norms. Can we speak here of a duty? Would you say that this view is linked to your own culture, to the sociocultural environment where you grew up and were educated? Do you think that it can even be linked to religious values?

I am thinking of ethnographic love as a form of mutual care and mutual investment. But moral worlds within the ethnographic encounter can be complex and even contradictory. It is not always the case that participants in an ethnographic relationship share the same values or morals, whether religious or secular. I think the ethnographic encounter asks for a mutual understanding and respect of the different moral worlds of the participants, and a shared understanding of the moral expectations that surround the ethnographic relationships. But so do most personal relationships.

You also suggest that love participates in the creation of our own humanity and that your friendship relations in the field have caused a change in your friendship relations at home. Could you develop, clarify and illustrate this view? What exactly has changed in the friendship relations that were developed beforehand? How was this change received? Were your friends sensitive or not to your own transformation?

I think my expectations of the practice of trust non-material forms of generosity, and reciprocity have evolved, but I think this has been much more internal than an externalized change.

In a more general way, does learning or researching "on" love influence the way of "experiencing", "doing" and "performing" love in daily life? How? Has your work on this topic impacted on your personal life, on your way of being "in love"?

Recognizing ethnographic love as a form of caring, mutuality, interpersonal investment, trust, and as a powerful emotion has helped me recognize this sentiment in other professional relationships as well. It has also helped me recognize its absence and to understand what it means to feel it in some encounters and situations and to notice its lack in others.

\section{Bibliographie}

Besteman C. (2014), « On Ethnographic Love », in R. SAnjek (dir.), Mutuality, Philadelphia, University of Pennsylvania Press, p. 259-294.

Dominguez V. R. (2000), « For a Politics of Love and Rescue », Cultural Anthropology, vol. $15, n^{\circ} 3, p .361-393$. 